\title{
Klamydia og uretritt
}

\author{
Når alminnelige sykdommer blir vanlige og mye omtalt, påvirkes også språkbruken - faguttrykk blir til \\ allmennord. Da må også skrivemåten endres.
}

Språket er alltid i endring, det gjelder også medisinsk fagspråk. Harald Moi, som er professor emeritus i klinisk venerologi, mener denne endringsprosessen i noen tilfeller ikke blir synliggjort godt nok i Tidsskriftet.

\section{Chlamydia eller klamydia?}

I Språkspalten i nr.7/2012 tok Moi opp skrivemåten for den seksuelt overførbare sykdommen som tradisjonelt er blitt bokstavert chlamydia - altså med ch- (1). Han går inn for den fornorskede betegnelsen klamydia. «Bakterien som forårsaker klamydiainfeksjon heter Chlamydia trachomatis, men på norsk bør bakterien hete klamydiabakterie,» skriver han (1). Som en konsekvens av dette må det da bli formene klamydiaprøve og klamydiapositiv. Adjektivet klamydial har allerede norsk ortografi etter regelen om at avledninger av latinsk grunnform blir skrevet på norsk. Moi nevner at dette adjektivet blir lite brukt, men om man skulle trenge det, er i hvert fall ikke bokstaveringen noe problem.

\section{Allmennordbøkene sier klamydia}

Språkrådet drøftet allerede i 1985 klamydia/ Chlamydia og vedtok at skriveformen skulle være k-. I 1995 kom saken opp på nytt, og man presiserte at endringen kun gjaldt sykdommen, ikke mikroorganismen (2). Den norvagiserte formen kom altså på plass i allmennspråket i 1985. Skrivemåten klamydia finnes nå i allmennordbøkene, inkludert Tanums store rettskrivningsordbok (3) og Bokmålsordboka og Nynorskordboka (4). Klamydia er mye omtalt i mediene med denne skrivemåten. I tekstarkivet Retriever er det over 20000 treff på klamydia, det er blitt et vanlig norsk ord.

\section{Medisinske ordbøker er på gli}

I de medisinske ordbøkene finner vi oppsettet: «klamydia se Chlamydia» både i Øyris ordbok og i Kunnskapsforlagets $(5,6)$. På henvisningsordet blir mikroorganismen forklart som henholdsvis klamydier og klamydiabakterier. Klamydiainfeksjon og klamydiaindusert atritt er egne oppslagsord i Kunnskapsforlagets ordbok. I Gyldendals medisinske ordbok er klamydia eget oppslag med forklaringen samme sted: sykdom forårsaket av mikroorganismen Chlamydia (se dette) (7).

Skrivemåten med k- blir mye brukt i sykehus og av helsemyndighetene. Endringen er i ferd med å festne seg.

\section{Leksikon dobbeltsikrer}

Ved søk på klamydia i Store norske leksikon på nett får vi denne viderehenvisningen: «Klamydia, se Chlamydia» (8), der vi finner hovedartikkelen (9). Hvis vi søker på det sammensatte uttrykket klamydiauretritt, kommer selve forklaringen: «Chlamydiaurethritt, betennelse i urinrøret...» (10). Og vi blir viderekoblet til Store medisinske leksikon Chlamydiaurethritt (11), der det står: også kjent som klamydiauretritt. Referansene er tatt med for å vise at skrivemåtene lever side om side. Det finnes sikkert mange flere eksempler fra medisinske ordbøker. Den tradisjonelle formen holder stand, men det er nødvendig å ta med den fornorskede.

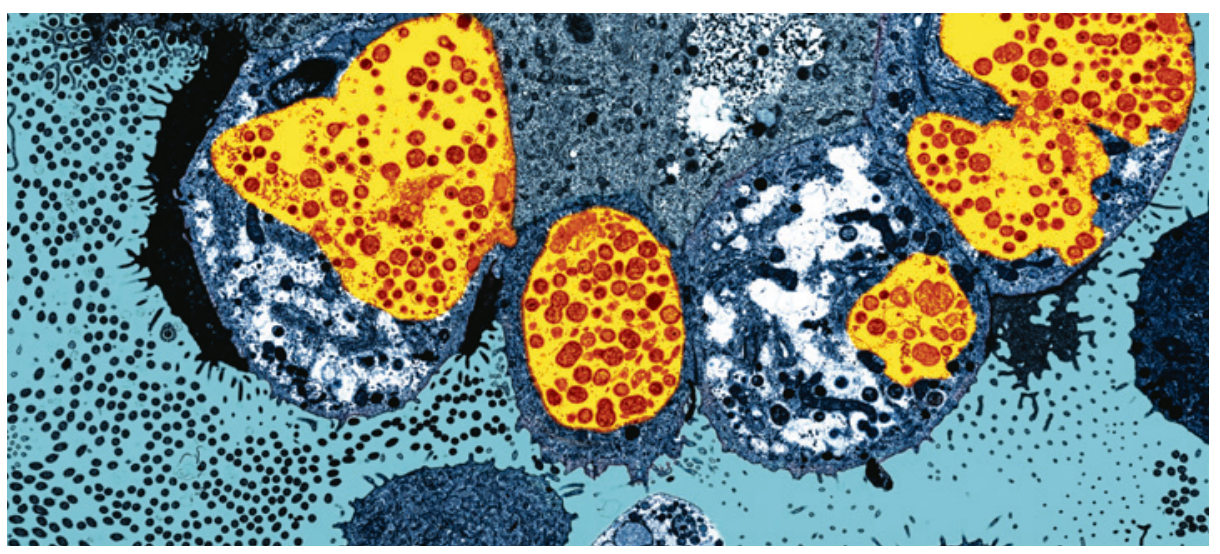

\section{Urethritt eller uretritt?}

Den vanligste manifestasjonen av betennelse som forårsakes av klamydia, er uretritt. Tidsskriftet har brukt den latinske/ engelske skrivemåten urethritt. I vår ordliste ble dette begrunnet slik: «urethra (alle ord vedrørende urethra skrives med $\mathrm{h}$ for å unngå forveksling med ureter)». Moi påpeker at betennelse i ureteren er en sjelden diagnose, gir ingen treff på tidsskriftet.no siden 2000 og gir derfor neppe grunn til forveksling med uretritt (1).

\section{Konklusjon}

Uretritt uten h- er greit. Klamydia med ker greit. Dette er de produktive formene, og de forekommer stadig oftere i innsendte manus. Tiden er inne til å endre praksis i Tidsskriftet. Vi har allerede gjort endringene i ordlisten vår på nett (12).

\section{Raida ødegaard}

raida.oedegaard@legeforeningen.no

Erlend Hem

Tidsskriftet

Raida $\emptyset$ degaard (f. 1946) er filolog og manusredaktør i Tidsskriftet.

Erlend Hem (f.1970) er dr.med. og konstituert sjefredaktør i Tidsskriftet.

Litteratur

1. Moi H. Klamydia eller chlamydia, uretritt eller urethritt? Tidsskr Nor Legeforen 2012; 132: 864

2. Språkrådet. Årsmelding 1995. www.sprakradet.no/ Toppmeny/Om-oss/Aarsmeldingar/ Aarsmelding 1995/\#2.1.9) (21.2.2013).

3. Klamydia. Wangensteen $B$, red. Tanums store rettskrivningsordbok. 9.utg. Oslo: Kunnskapsforlaget, 2005.

4. Klamydia. Bokmålsordboka/Nynorskordboka. www.nob-ordbok.uio.no/perl/ordbok.cgi?OPP= chlamydia\&ordbok=bokmaal (21.2.2013)

5. Klamydia. Øyri A. Norsk medisinsk ordbok. 9. utg Oslo: Det Norske Samlaget, 2011.

6. Klamydia. Nylenna M. Medisinsk ordbok. 7. utg. Oslo: Kunnskapsforlaget, 2009.

7. Klamydia. Lindskog BI. Gyldendals store medisinske ordbok. 2. utg. Oslo: Gyldendal, 2003.

8. Klamydia. Store norske leksikon. http://snl.no/ klamydia (20.2.2013).

9. Chlamydia. Store norske leksikon. http://snl.no/ Chlamydia (20.2.2013)

10. Klamydiauretritt. Store norske leksikon. http://snl.no/.search?query=klamydiauretritt $\&$ search $=(20.2$.2013).

11. Chlamydiaurethritt. Store norske leksikon. http://snl.no/.sml_artikkel/chlamydiaurethritt [19.2.2013)

12. Ordliste. Tidsskrift for Den norske legeforening http://tidsskriftet.no/Innhold/Forfatterveiledningen/ Spraak/Ordliste/K (19.2.2013). 